\title{
Microsatellite markers for Pinus pinaster Ait.
}

\author{
Stéphanie Mariette ${ }^{\mathrm{a}, \#}$, David Chagnéa,\#, Stéphane Decroocq ${ }^{\mathrm{a}}$, Giuseppe Giovanni \\ Vendramin $^{b}$, Céline Lalanne ${ }^{\mathrm{a}}$, Delphine Madur ${ }^{\mathrm{a}}$ and Christophe Plomion ${ }^{\mathrm{a}, *}$ \\ ${ }^{1}$ INRA, BP45, Laboratoire de Génétique et Amélioration des Arbres Forestiers, 33610 Cestas, France \\ ${ }^{2}$ Istituto Miglioramento Genetico Piante Forestali, CNR, Via A. Vannucci 13, 50134 Firenze, Italy
}

(Received 26 January 2000; accepted 13 June 2000)

\begin{abstract}
Simple sequence repeats (SSRs) or microsatellites are valuable tools for genome mapping and population genetic studies for as they are codominant and highly polymorphic markers. Seventy-six SSR primer pairs from four Pinus species were tested to amplify microsatellites in Pinus pinaster. Twenty-six primer pairs were stemmed from a microsatellite library on $P$. pinaster and the other primer pairs were obtained in other species of the same genus ( $P$. radiata, $P$. strobus and $P$. halepensis). Only three out of the 76 SSR primer pairs amplified at a single polymorphic locus in $P$. pinaster. The Mendelian inheritance of those three primer pairs was studied and their genetic map position was determined. The number of alleles and the level of heterozygosity were assessed in an analysis of a sample of 196 trees. The development of microsatellites in Pinus species has been reported to be a difficult task because of the size and complexity of their genome. The results of this study showed that cross-species amplification was quite unsuccessful.
\end{abstract}

Pinus pinaster / genetic variability / genetic mapping / microsatellite / cross-species amplification

Résumé - Marqueurs microsatellites chez Pinus pinaster Ait. Les microsatellites (SSRs) sont des outils de choix pour la cartographie génétique et les études de génétique des populations parce qu'ils sont des marqueurs codominants et très polymorphes. Soixante-seize paires d'amorces de quatre espèces de pin ont été utilisées afin d'amplifier des microsatellites chez Pinus pinaster. Vingt-neuf paires d'amorces étaient issues d'une banque enrichie en microsatellites sur $P$. pinaster et les autres paires d'amorces avaient été obtenues sur d'autres espèces du même genre ( $P$. radiata, $P$. strobus et $P$. halepensis). Sur un total de 76 paires d'amorces, seulement trois ont amplifié un seul locus microsatellite polymorphe chez $P$. pinaster. Leur ségrégation mendélienne a été étudiée et chaque locus a été localisé sur une carte génétique. Le nombre d'allèles et l'hétérozygotie ont été ensuite évalués en analysant un échantillon de 196 arbres. Le développement de microsatellites chez les espèces du genre Pinus s'est révélée difficile en raison de la taille et de la complexité de leur génome. Les résultats de cette étude ont montré que l'amplification inter-espèces n'a rencontré que peu de succès.

Pinus pinaster / variabilité génétique / cartographie génétique / microsatellite / amplification inter-spécifique

Pinus pinaster Ait. is one of the most abundant conifer in South-Western Europe. It is an important species from an ecological (swamp draining and dunes protection) and economical (wood production, pulp and paper making industry) point of view. In France, it cov- ers $1.4 \mathrm{M}$ hectares which represents $10 \%$ of the forest surface. A breeding programme for $P$. pinaster was started in the sixties. It has now reached its third generation and has allowed the deployment of improved varieties. Genetic diversity studies were performed using terpenic,

* Correspondence and reprints

Tel. (33) 05579790 76; Fax. (33) 05579790 88; e-mail: plomion@ pierroton.inra.fr

\# These authors have contributed equally to this work. 
protein, allozymic and chloroplast microsatellite markers throughout the natural range of this species (Baradat et al., 1991 [1]; Barhman et al., 1992 [2]; Petit et al., 1995 [14]; Vendramin et al., 1998 [19]). Nuclear microsatellites are valuable codominant multiallelic DNA markers but not yet available in $P$. pinaster for testing the validity of controlled crosses, for fingerprinting clones and for studying the genetic diversity of the provenances used in the breeding programme. In this study, our aim was to test 76 primer pairs from four Pinus species to amplify microsatellite loci in $P$. pinaster.

We adopted two strategies to amplify microsatellites in $P$. pinaster. First, we tested 47 existing primer pairs, as described in the literature or by personal communication, from three other Pinus species (table I). Second, we constructed an enriched microsatellite library, from which we designed and tested 29 primer pairs.

The microsatellite library, enriched with CA and GA repeats, was constructed from $P$. pinaster genomic DNA, as described by Edwards et al. (1996) [8]. The protocol was modified for hybridisation and washing as followed. Nylon membranes were prehybridised in 6X SSC 5X Denhardt's $1 \%$ SDS at $65^{\circ} \mathrm{C}$ for $48 \mathrm{~h}$ renewing the solution after $24 \mathrm{~h}$. Hybridisation was performed in the same conditions for $20 \mathrm{~h}$. Washing was performed three times in $2 \mathrm{X} \mathrm{SSC}, 1 \% \operatorname{SDS~} 65^{\circ} \mathrm{C}$ for $15 \mathrm{~min}$, then $1 \mathrm{X} \mathrm{SSC}, 1 \%$ SDS for $10 \mathrm{~min}$ at $65^{\circ} \mathrm{C}$. A first PCR was performed on DNA that was bound and then eluted from the membrane. PCR products were used for a second round of enrichment. After this second step of enrichment, PCR products were cloned according to the protocol outlined in the Topo TA Cloning kit (Invitrogen, The Netherlands). They were sequenced using LI-COR automatic sequencers 4000 and 4000L (LI-COR Inc., Nebraska, USA). A total of 65 clones containing a microsatellite were detected from 80 clones randomly chosen from the library. Primers were designed for 29 SSRs using the primer software (version 5.0, Whitehead Institute for Biomedical Research, 1991).

The extraction of DNA and the amplification of microsatellites were performed as followed. Genomic DNA was extracted from needles as described by Doyle and Doyle (1991) [5]. The PCR was carried out in a Thermal Cycler Perkin Elmer GeneAmp PCR system 9600, using 0.4 units of Gibco BRL Taq Polymerase (Life Technologies, Inc. Gaithersburg MD, USA), and approximately $6 \mathrm{ng}$ of genomic DNA in a total volume of $10 \mu \mathrm{l}$ containing $200 \mu \mathrm{M}$ of each nucleotide and $0.2 \mu \mathrm{M}$ of each primer. Optimized $\mathrm{MgCl}_{2}$ concentrations are indicated in table I. Each forward primer was labelled with the infra-red fluorescent dye IR800 (purchased at MWG Biotech). After a preliminary denaturation step at $94^{\circ} \mathrm{C}$ for $4 \mathrm{~min}, \mathrm{PCR}$ amplifications were performed for 35 cycles under the following conditions: $30 \mathrm{~s}$ at $94^{\circ} \mathrm{C}, 30 \mathrm{~s}$ at the annealing temperature (see table I), and $45 \mathrm{~s}$ at $72^{\circ} \mathrm{C}$, with a final extension step of 10 minutes at $72{ }^{\circ} \mathrm{C}$. After the amplification, $2 \mu \mathrm{l}$ of PCR product were mixed with $7 \mu$ l of loading buffer $(78 \%$ formamide, $10 \mathrm{mM}$ EDTA $\mathrm{pH} 7.6,0.1 \%$ bromophenol blue and $0.1 \%$ xylene cyanol), heated for $5 \mathrm{~min}$ at $75^{\circ} \mathrm{C}$ and quickly cooled on ice. Afterwards $1 \mu$ of denatured SSR fragments was loaded into a $25 \mathrm{~cm}$ long denaturating gel containing $8 \%$ acrylamide/bisacrylamide (19:1), $6 \mathrm{M}$ urea and 0.4X TBE (134 mM TRIS, $45 \mathrm{mM}$ boric acid, $2.5 \mathrm{mM}$ EDTA). Electrophoresis was performed in the LI-COR automated sequencers using a $1 \mathrm{X}$ TBE running buffer at $1500 \mathrm{~V}, 40 \mathrm{~mA}$ and $45^{\circ} \mathrm{C}$ of plate temperature. The RFLPscan version 3.0 (Scanalytics) software was used to score the SSR fragments.

Only three (one from $P$. halepensis and two from $P$. pinaster) out of the 76 primer pairs screened amplified at a single highly polymorphic locus in $P$. pinaster

Table I. Amplification of Pinus microsatellites in Pinus pinaster.

\begin{tabular}{|c|c|c|c|c|c|c|}
\hline \multirow[t]{2}{*}{ Species (number of primer pairs tested) } & \multirow[t]{2}{*}{ Sub-section } & \multicolumn{2}{|c|}{ Amplification $^{\mathrm{d}}$} & \multicolumn{3}{|c|}{ Banding pattern ${ }^{\mathrm{e}}$} \\
\hline & & + & - & SML & SPL & $\mathrm{C}$ \\
\hline Pinus radiata $(\mathrm{n}=11)^{\mathrm{a}}$ & Attenuatae & $73 \%$ & $27 \%$ & $12 \%$ & $0 \%$ & $88 \%$ \\
\hline Pinus strobus $(\mathrm{n}=11)^{\mathrm{b}}$ & Strobi & $100 \%$ & $0 \%$ & $73 \%$ & $0 \%$ & $27 \%$ \\
\hline Pinus halepensis $(\mathrm{n}=25)^{\mathrm{c}}$ & Halepenses & $68 \%$ & $32 \%$ & $23 \%$ & $6 \%$ & $71 \%$ \\
\hline Pinus pinaster $(\mathrm{n}=29)$ & Australes & $79 \%$ & $21 \%$ & $34 \%$ & $9 \%$ & $57 \%$ \\
\hline
\end{tabular}

\footnotetext{
a 7 pairs from G.F. Moran (unpublished results), 2 pairs from [17] Smith and Devey (1994), 2 pairs from [10] Fisher et al. (1998).

b 4 pairs from [6] Echt et al. (1996) and 7 pairs available at URL http:/www.resgen.com.

c 25 pairs from G.G. Vendramin (unpublished).

$\mathrm{d}+$ : amplification; - : no amplification.

e SML: single monomorphic locus; SPL: single polymorphic locus; C: complex banding pattern.
} 
Table II. Characteristics of three primer pairs for amplifying maritime pine microsatellite loci, with expected $\left(\mathrm{H}_{\mathrm{E}}\right)$ and observed $\left(\mathrm{H}_{0}\right)$ levels of heterozygosity based on 196 individuals.

\begin{tabular}{|c|c|c|c|c|c|c|c|c|c|c|}
\hline Locus & Primers $\left(5^{\prime} \rightarrow 3^{\prime}\right)$ & $\begin{array}{c}\text { Micro- } \\
\text { satellite } \\
\text { sequence }\end{array}$ & $\begin{array}{l}\text { Length } \\
\text { of PCR } \\
\text { product }\end{array}$ & $\mathrm{T}_{\mathrm{a}}\left({ }^{\circ} \mathrm{C}\right)^{\mathrm{a}}$ & $\underset{(\mathrm{mM})}{\mathrm{MgCl}_{2}}$ & $\begin{array}{c}\text { Number } \\
\text { of } \\
\text { alleles }\end{array}$ & $\mathrm{H}_{\mathrm{E}}$ & $\mathrm{H}_{\mathrm{O}}$ & $\underset{\text { location }^{\mathrm{b}}}{\text { Map }}$ & $\begin{array}{c}\text { EMBL } \\
\text { Accession } \\
\text { number }\end{array}$ \\
\hline FRPP91 & $\begin{array}{l}\text { F:GTACTCCCACATAAAATGAGACTT } \\
\text { R:CCGAAATACATTGCAGGTTA }\end{array}$ & $(\mathrm{CT})_{20}$ & 168 & 61 & 2.25 & 25 & 0.862 & 0.684 & 9 & AJ012085 \\
\hline FRPP94 & $\begin{array}{l}\text { F:GGCAAACCTCTTTTAGAGTGC } \\
\text { R:TTTGTCGATTTTTCTTGAAATCTAA }\end{array}$ & $(\mathrm{CT})_{22}$ & 162 & 60 & 2.5 & 17 & 0.726 & 0.571 & 5 & AJ012086 \\
\hline ITPH4516 & $\begin{array}{l}\text { F:TGATGCAAACAAGTTCCATG } \\
\text { R:AGCACTCGCTAAACTATGAAGG }\end{array}$ & $(\mathrm{CT})_{27}$ & 159 & 61 & 2.25 & 20 & 0.894 & 0.684 & 3 & AJ012087 \\
\hline
\end{tabular}

${ }^{\mathrm{a}} \mathrm{T}_{\mathrm{a}}$, annealing temperature; ${ }^{\mathrm{b}}$ Linkage group according to the genetic map of Costa et al. (2000).

See also URL http://www.pierroton.inra.fr/genetics/pinus/map2.html

genomic DNA (table I). Their Mendelian pattern of inheritance was tested and their allelic variations were examined for 196 individuals, that belonged to eight different populations from southwest France. The characteristics of these three SSRs are summarized in table II. Each microsatellite locus revealed a high amount of polymorphism (mean number of alleles $=20.7$ ). The average observed heterozygosity was 0.65 . We used a haploid (megagametophyte) mapping pedigree to show that they exhibit a Mendelian pattern of inheritance and we could position them in a previously constructed linkage map (Costa et al., 2000 [4]). About a third of the primer pairs analyzed in this study resulted in single locus-specific amplification. Among these loci, 87.5\% were monomorphic and $12.5 \%$ were polymorphic. The majority of the remaining primer pairs gave either no amplification $(22.4 \%)$ or produced multiband patterns (46\%) (table I). The difficulty of developing informative (single polymorphic locus) microsatellites has already been reported in other conifer species (Echt et al., 1996 [6]; Pfeiffer et al., 1997 [15]) and can be attributed to their large genome size and complexity (Wakamiya et al., 1993 [20]; Kinlaw and Neale, 1997 [12]).

In this study, we showed that only one primer pair from other Pinus species (P. halepensis) could be transferred to $P$. pinaster. According to Farjon (1984) [9], $P$. radiata belongs to the same section as $P$. pinaster whereas $P$. strobus belongs to the section Strobus and $P$. halepensis to the section Pinea. However, a natural hybrid between $P$. halepensis and $P$. pinaster was mentioned by Schütt (1959) [16], which may explain our result. As reported by Echt and May-Marquardt (1997) [7], we also found that SSR information do not transfer across Pinus species. However, ten polymorphic SSRs markers developed in $P$. halepensis produced single vari- able bands segregating in a Mendelian manner in the species P. brutia (G.G. Vendramin, personal communication). In this case, cross-species amplification seemed to be easier because these Pinus species show a low degree of divergence (Bucci et al., 1998 [3]). Similarly, some studies have shown that SSRs isolated from several species amplify the corresponding and polymorphic PCR products in closely related species. Kijas et al. (1995) [11] tested two primer sets in 10 different Citrus species and two related genera and found conservation of the sequences. Using 17 sets of primers developed from sessile oak, Quercus petraea, Steinkellner et al. (1997) [18] found that two of the loci were polymorphic in all the Quercus species tested. In general, the success of the amplification diminishes with increasing species divergence (Steinkellner et al., 1997 [18]; Whitton et al., 1997 [21]; Lefort et al., 1999 [13]). Further development of $P$. pinaster microsatellites will be focused on an enriched cDNA library.

Acknowledgements: We thank Cécile Cabrero and Audrey Lartigue for their partnership in this work, Gavin Moran for providing unpublished Pinus radiata primer pairs. We thank two anonymous reviewers for their useful remarks on a previous version of the manuscript. This work was supported by grants from France (Ministère de l'Agriculture et de la Pêche-DERF n ${ }^{\circ}$ 61.21.04/98), and the European Union (INCO, ERBIC-08CT-970200).

\section{REFERENCES}

[1] Baradat P., Marpeau A., Walter J., Terpene markers, in: Müller-Starck G., Ziehe M. (Eds.), Genetic variation in European populations of forest trees, Sauerländer, Francfort, 1991, pp. 40-66. 
[2] Barhman N., Baradat P., Petit R.J., Structuration de la variabilité génétique du Pin maritime dans l'ensemble de son aire naturelle, in : Colloque international en hommage à Jean Pernès, Publications du Bureau des Ressources Génétiques, 1992, pp. 352-368.

[3] Bucci G., Anzidei M., Madaghiele A., Vendramin G.G., Detection of haplotypic variation and natural hybridization in halepensis-complex pine species usng chloroplast simple sequence repeat (SSR) markers, Mol. Ecol. 7 (1998) 1633-1643.

[4] Costa P., Pot D., Dubos C., Frigerio J.M., Pionneau C., Bodénès C., Bertocchi E., Cervera M.T., Remington D.L., Plomion C., A genetic map of maritime pine based on AFLP, RAPD and protein markers, Theor. Appl. Genet. 100 (2000) $39-48$.

[5] Doyle J.J., Doyle J.L., Isolation of plant DNA from fresh tissue, Focus 12 (1990) 13-15.

[6] Echt C.S., May-Marquardt P., Hseih M., Zahorchak R., Characterization of microsatellite markers in Eastern white pine, Genome 39 (1996) 1102-1108.

[7] Echt C.S., May-Marquardt P., Survey of microsatellite DNA in pine, Genome 40 (1997) 9-17.

[8] Edwards K.J., Barker J.H.A., Daly A., Jones C., Karp A., Microsatellite librairies enriched for several microsatellite sequences in plants, BioTechniques 20 (1994) 758-760.

[9] Farjon A., Pines: drawings and descriptions of the genus Pinus, Brill E.J. (Ed.), Leiden, 1984.

[10] Fisher P.J., Richardson T.E., Gardner R.C., Characteristics of single-and multi-copy microsatellites from Pinus radiata, Theor. Appl. Genet. 96 (1998) 969-979.

[11] Kijas J.M.H., Fowler J.C.S., Thomas M.R., An evolution of sequence tagged microsatellite site markers for genetic analysis within citrus and related species, Genome 38 (1995) 349-355.

[12] Kinlaw C.S., Neale D.B., Complex gene families in pine genomes, Trends Plant Sci. 2 (1997) 356-359.

[13] Lefort F., Brachet S., Frascaria-Lacoste N., Edwards K.J., Douglas G.C., Identification and characterization of microsatellite loci in ash (Fraxinus excelsior L.) and their conservation in the olive family (Oleaceae), Mol. Ecol. 8 (1999) 1088-1090.

[14] Petit R.J., Barhman N., Baradat P.H., Comparison of genetic differentiation in maritime pine (Pinus pinaster Ait.) estimated using isozyme, total proteine and terpenic loci, Heredity 75 (1995) 382-389.

[15] Pfeiffer A., Olivieri A.M., Morgante M., Identification and characterization of microsatellites in Norway spruce (Picea abies K.). Genome 40 (1997) 1-9.

[16] Schütt P., Züchtung mit Kiefern Teil 2. Kreuzungen, Resistenzzüchtung und Zytologie. Mitt. Bundesforsch. Forstund Holzwirt. Forstgenetik und Forstpflanzenzüchtung, 42 (1959) 1-40.

[17] Smith D.N., Devey M.E., Occurence and inheritance of microsatellites in Pinus radiata, Genome 37 (1994) 977-983.

[18] Steinkellner H., Lexer C., Turetschek E., Glössl J., Conservation of $(\mathrm{GA})_{\mathrm{n}}$ microsatellite loci between Quercus species, Mol. Ecol. 6 (1997) 1189-1194.

[19] Vendramin G.G., Anzidei M., Madaghiele A., Bucci G., Distribution of genetic diversity in Pinus pinaster Ait. as revealed by chloroplast microsatellites, Theor. Appl. Gen. 97 (1998) 456-463.

[20] Wakamiya I., Newton R.J., Johnston J.S., Price H.J., Genome size and environmental factors in the genus Pinus, Am. J. Bot. 80 (1993) 1235-1241.

To access this journal online: www.edpsciences.org 